\title{
GAME EDUKASI MERAWAT DIRI UNTUK ANAK TUNAGRAHITA TINGKAT SEKOLAH DASAR BERBASIS KINECT XBOX 360
}

\author{
Fatah Yasin Al Irsyadi \\ Fakultas Komunikasi dan Informatika, Program Studi Informatika \\ Universitas Muhammadiyah Surakarta \\ Email: fatah.yasin@ums.ac.id \\ Siti Laila Mar'atus Sholihah \\ Fakultas Komunikasi dan Informatika, Program Studi Informatika \\ Universitas Muhammadiyah Surakarta \\ Email: laylainmemoriam@gmail.com \\ Endah Sudarmilah \\ Fakultas Komunikasi dan Informatika, Program Studi Informatika \\ Universitas Muhammadiyah Surakarta \\ Email: Endah.Sudarmilah@ums.ac.id
}

\begin{abstract}
ABSTRAK
Anak Berkebutuhan Khusus (ABK) tunagrahita adalah anak yang memiliki kemampuan intelektual bawah rata - rata anak normal. Agar dapat mandiri dalam merawat dirinya, maka anak tunagrahita perlu dibimbing dan diajari cara merawat diri secara berulang ulang. Metode pembelajaran pada anak tunagrahita berbeda dengan anak normal. Banyak metode belajar yang telah digunakan, namun berpegang pada prinsip yang sama yaitu harus menarik, mudah diterima dan diingat oleh anak tunagrahita. Salah satu metode yang digunakan dalam proses belajar anak tunagrahita adalah menggunakan media game. Penelitian ini bertujuan untuk merancang dan membuat sebuah aplikasi game edukasi yang berkaitan dengan kemandirian anak tunagrahita. Game edukasi ini memanfaatkan teknologi kinect Xbox 360 sehingga menarik dan interaktif. Penelitian dilakukan di sekolah SLB-C YPSLB Surakarta dengan kurikulum sekolah SLB sebagai acuan utamanya. Penelitian diawali dengan mencermati beberapa tingkat kategori anak tunagrahita untuk mengetahui kemampuan masing-masing dalam menangkap informasi dan berkomunikasi. Penelitian juga melihat kemampuan siswa dalam merawat diri, karena berdasarkan wawancara dengan guru kemampuan mereka dalam merawat diri adalah berbeda-beda. Pembuatan game ini menggunakan software utama Unity3D, Kinect SDK dan software pendukung 3DsMax, audacity. Pengujian dilakukan dengan mendemokan aplikasi game edukasi ini kepada anak tunagrahita SDLB-C YPSLB Surakarta dan mereka diberi kesempatan untuk mencoba dengan didampingi guru. Berdasarkan hasil kuisioner yang diisi oleh guru SLB-C YPSLB Surakarta dapat dinyatakan bahwa game ini mudah dimainkan oleh anak tunagrahita kategori ringan, game ini sangat menarik dan bisa digunakan untuk melatih motorik anak serta dapat digunakan guru sebagai salah satu media pembelajaran.
\end{abstract}

Kata kunci: anak tunagrahita, game edukasi, unity3D, kinect Xbox 360, audacity.

\begin{abstract}
Children with Special Needs (ABK), tunagrahita is a child who has below average intellectual ability - average normal children. In order to be independent in taking care of himself, so children with intellectual challenges need to be guided and taught how to care for themselves over and over again. Tunagrahita method of learning in children is different from normal children. Many learning methods that have been used, but adhering to the same principles that should be attractive, easily accepted and remembered by children with intellectual challenges. One of the methods used in the learning process retarded child is using the media game. This research aims to design and create an educational game application relating to the independence of children with intellectual challenges. This educational game utilizes Xbox 360 kinect technology so interesting and interactive. The study was conducted in schools SLB-C YPSLB Surakarta with SLB school curriculum as the main reference. The study begins by examining some level categories of children with intellectual challenges to determine the ability of each to capture and communicate information. Research also see students' ability to care for themselves, because it is based on interviews with teachers their ability to care for themselves is different. Making
\end{abstract}


this game using Unity3D main software, Kinect SDK and supporting software 3DsMax, audacity. Testing is done by demonstrating the application of this educational game for children with intellectual challenges SDLB-C YPSLB Surakarta and they were given the opportunity to try accompanied by teachers. Based on the results of questionnaires filled out by teachers SLB-C YPSLB Surakarta can be stated that the game is easily played by children with intellectual challenges lightweight category, this game is very exciting and can be used to train the child's motor and can be used by teachers as a learning medium.

Keywords: tunagrahita children, education game, unity3D, kinect Xbox 360, audacity.

\section{PENDAHULUAN}

Kemampuan intelektual dibawah rata-rata yang dimiliki oleh anak tunagrahita menyebabkan mereka lamban dalam mempelajari hal baru dan mengerjakan tugas-tugas sederhana, kesulitan dalam mempelajari dengan kemampuan abstrak, serta mudah lupa dengan apa yang baru saja dipelajari kecuali jika latihan terus menerus. Menurut Saptunar, dalam skripsinya yang bejudul "Meningkatkan Keterampilan Menyetrika Pakaian Anak Tunagrahita Sedang" mengungkapkan proses pembelajaran menyetrika pakaian dengan menggunakan metode latihan dilakukan dengan peraga dan bertahap serta latihan berulang-ulang, dapat meningkatkan pengetahuan dan ketrampilan anak tunagrahita. Anak tunagrahita bahkan kurang mampu dalam merawat atau mengurus diri sendiri, seperti makan, mengurus kebersihan diri, memakai sepatu, berpakaian dan lain-lain. Mereka memerlukan latihan khusus dan berulang-ulang untuk mempelajari kemampuan dasar merawat diri. [2]

Sekolah luar biasa (SLB) merupakan salah satu lembaga pendidikan dengan tujuan selain untuk memenuhi tujuan pendidikan nasional juga untuk menggali kemampuan yang dimiliki siswa dengan kebutuhan khusus secara optimal. Salah satu materi pelajaran yang diberikan pada siswa SLB adalah merawat diri. Selama ini pembelajaran cara merawat diri disampaikan dengan pelatihan khusus, yaitu menggunakan alat peraga yang diperagakan kepada para siswa. Banyaknya murid yang harus diampu oleh satu guru untuk memberikan pengenalan cara merawat anggota tubuh, sering membuat para guru kewalahan. Effendi dalam Usti, menyatakan seseorang dikategorikan tunagrahita apabila memiliki tingkat kecerdasan yang sedemikian rendahnya atau dibawah normal, sehingga untuk melihat perkembangannya memerlukan bantuan atau layanan secara spesifik termasuk dalam pendidikannya. Anak tunagrahita mempunyai ingatan dan perhatian lemah, tidak mampu memperhatikan sesuatu hal dengan serius dan lama, perhatian anak tunagrahita akan sering berpindah pada persoalan lain dalam waktu sekejap dan dalam hal memperhatikan pelajaran anak tunagrahita cepat merasa bosan. [4]

Oleh karena itu, penulis membuat media pembelajaran berupa aplikasi game edukasi sebagai sarana pendidikan merawat diri, sekaligus memanfaatkan teknologi Kinect untuk membantu para guru agar lebih bervariasi dalam menyampaikan materi. Menurut Budiman dalam Al Irsyadi, kinect adalah teknologi baru perangkat permainan utuk memindai gerakan manusia yang diolah dalam fungsi suatu animasi atau permainan. [1]

Teknologi sensor gerak Kinect dikenalkan oleh Microsoft. Kinect Xbox360 pertama kali digunakan sebagai video game console, namun hingga sekarang teknologi Kinect menjadi sangat populer penggunaannya sebagai teknologi interaktif. Keunggulan teknologi kinect diantaranya menggabungkan gerakan dalam pembelajaran, multi sensorik yang dapat meningkatkan pengalaman dalam pembelajaran dengan gerakan, gerak fleksibel dalam bermain untuk meningkatkan pemahaman dan penguasaan pengetahuan serta ketrampilan, pemain dapat mengalami interaksi secara bersamaan serta keunggulan pada hal keselamatan serta kesehatan yaitu sterilitas sebab pemain hanya perlu mengoperasikan sistem dengan gerakan tubuh tanpa perlu menyentuh peralatan lain [5].

Menurut Sudarmilah, 'et.al', menyatakan bahwa aplikasi game dapat digunakan sebagai solusi alternatif untuk mengatasi kesulitan dalam belajar, karena game memberikan proses pembelajaran yang santai dan menyenangkan. Game engine dapat digunakan berdasarkan tujuan sistem pembuatan atau target pasar. Dalam pembuatan aplikasi, diperlukan pertimbangan analisis kebutuhan dan kriteria teknologi yang dimiliki oleh setiap game engine, yang bertujuan untuk meningkatkan kemampuan kognitif anak-anak. [3]

Game ini untuk anak tunagrahita yang memerlukan pelatihan kemandirian dan diharapkan dapat membuat suasana kelas menjadi menyenangkan dan menarik, tidak membosankan sehingga menumbuhkan minat belajar anak tunagrahita dan dapat menerima pelajaran dengan mudah. 


\section{METODOLOGI}

Penelitian ini dimulai dengan melakukan pengamatan terhadap masalah yang muncul dalam proses pembelajaran sekaligus mengidentifikasi penyelesaian yang dapat digunakan untuk mengatasi masalah tersebut. Penulis melakukan wawancara terhadap guru kelas 1 SD SLB-C YPSLBC Surakarta untuk mendapatkan data. Hasil wawancara adalah sebagai berikut:

a. Banyak metode belajar yang diterapkan di SLB-C YPSLBC Surakarta, salah satunya adalah bermain, sehingga guru berharap game yang dibuat mengutamakan unsur edukasi sesuai kurikulum dan mampu meningkatkan minat belajar siswa.

b. Kondisi siswa yang kurang mampu memperhatikan materi yang disampaikan oleh guru dan cepat merasa bosan, menuntut adanya pengembangan media pembelajaran yang memiliki daya tarik dan bersifat interaktif, salah satunya adalah memenfaatkan media komputer.

c. Bimbingan dan pendampingan dalam menerima pembelajaran di kelas diperlukan oleh siswa, terlebih lagi ketika berinteraksi dengan media belajar yang baru dan asing bagi mereka.

d. Kurikulum yang bersifat tematik mengharuskan guru mengaitkan beberapa mata pelajaran dalam sebuah tema tertentu untuk diberikan kepada siswa di kelas.

e. Secara umum, para guru menghendaki agar game bisa dioperasikan pada perangkat komputer yang tidak memerlukan spesifikasi yang tinggi, tidak melanggar hukum yang berlaku, tidak mengandung unsur pornografi, penipuan atau perilaku kejahatan lainnya.

f. Secara operasional, para guru menghendaki bahwa game yang dibuat mudah digunakan dan fitur-fiturnya tidak rumit sehingga layak digunakan sebagai salah satu media pembelajaran di SLB

\section{PERANCANGAN SISTEM}

\subsection{Gambaran Umum}

Gambaran umum dari game edukasi yang dibuat adalah sebagai berikut:

a) Game edukasi ini berisi materi belajar merawat diri untuk anak tunagrahita kelas 1 SD-SLBC YPSLBC Surakarta.

b) Unity $3 D$ digunakan untuk membangun game ini. Game controller yang digunakan adalah perangkat Kinect Xbox 360 yang berfungsi untuk memainkan game.

c) Game ini terdiri dari 4 scene, yaitu scene 1 hingga 4.

d) Pada halaman awal game, terdapat 3 menu utama, yaitu mulai, petunjuk dan Keluar. Pengguna bisa memilih menu mulai untuk memulai permainan.

e) Menu petunjuk yang berisi tutorial berbasis teks yang menjelaskan bagaimana permainan pada game ini dijalankan. Selain itu tersedia menu demo yang berisi video tutorial cara bermain game ini.

f) Pada setiap permainan terdapat tombol setuju untuk memainkan misi atau permainan dan tombol untuk tidak jadi memainkan misi, yang bisa dipilih oleh pengguna.

g) Jika selesai memainkan salah satu misi, maka pengguna bisa melanjutkan memainkan misi yang lain atau keluar dari permainan.

\subsection{Storyboard}

Berdasarkan gambaran umum yang telah dijelaskan, proses selanjutnya adalah pembuatan storyboard yang merupakan serangkaian sketsa visual untuk menggambarkan urutan atau alur dari game edukasi. Storyboard dari game edukasi ditunjukan pada gambar 1. 


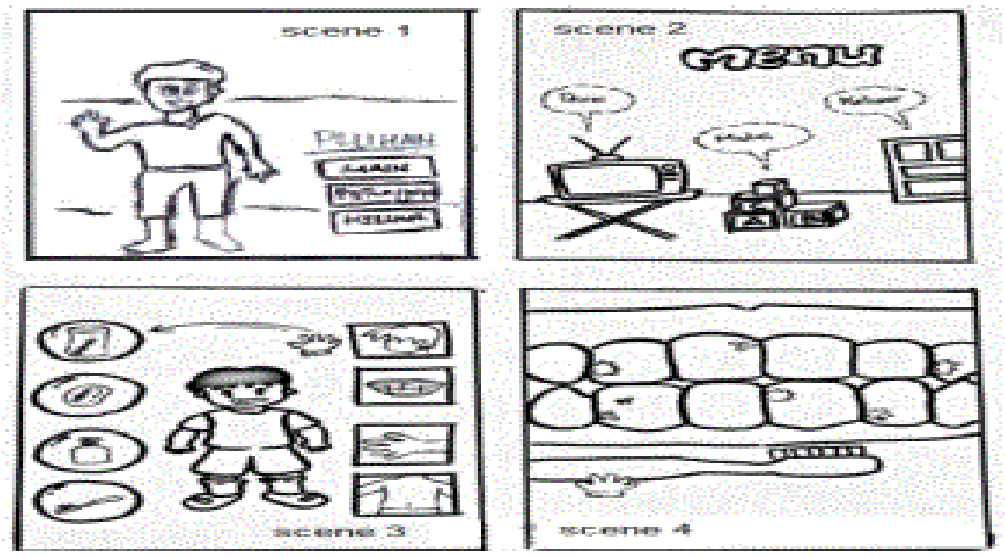

Gambar 1. Storyboard Game Merawat Diri

Secara keseluruhan game edukasi ini terdiri dari 4 scene, yaitu scene 1 sampai 4. Scene 1 merupakan halaman awal permainan yang berisi tutorial atau petunjuk cara memainkan game, memulai permainan dan keluar atau tidak jadi memainkan game. Scene 2 merupakan halaman menu utama yang berisi pilihan tutorial video merawat diri dan mulai misi atau permainan. Scene 3 merupakan halaman demo apabila pada scene 2 pengguna memilih "Demo". Scene 4 merupakan halaman misi atau permainan, yang merupakan halaman lanjutan apabila pada scene 2 pengguna memilih "Mulai". Permainan dimulai dengan menggosok gigi dan bisa dilanjutkan ke permainan atau misi memotong kuku apabila menggosok gigi telah selesai. Jenis game ini adalah drag and drop sehingga pengguna tinggal menggerakkan tangan kanannya di depan sensor kinect Xbox 360 dengan jarak sesuai ketentuan, yaitu maksimal 1,6 meter.

\subsection{Pembangunan Sistem dan Testing}

Aplikasi game edukasi merawat diri dibangun menggunakan perangkat lunak Unity 3D. Setelah itu diuji di SLB-C YPSLB Surakarta dengan melibatkan para siswa terutama siswa-siswa kelas 1 SD yang didampingi oleh guru pengajar. Kuesioner diberikan pada guru-guru pengajar dengan tujuan untuk menganalisa aplikasi yang telah diujicobakan.

\section{HASIL DAN PEMBAHASAN}

Hasil dari penelitian ini adalah Aplikasi Game Edukasi Pelatihan Merawat Diri Untuk Anak Berkebutuhan Khusus Tunagrahita Berbasis Kinect Xbox 360. Game ini dibuat dengan Software Unity 3D, bahasa pemrograman C\#, software 3DS Max 2011 untuk pembuatan objek 3 dimensi. Sedangkan untuk pengolahan suara menggunakan Adobe Audition 3.0. Game ini berisi pelatihan merawat kebersihan anggota tubuh beserta pengenalan alat-alat yang bisa digunakan untuk merawatnya khususnya gigi dan kuku tangan. Berikut pembahasan hasil dari penelitian game edukasi pelatihan merawat diri untuk anak tunagrahita berbasis kinect Xbox 360.

Ketika memainkan game ini perangkat sensor kinect harus sudah terpasang pada komputer dan pengguna harus berasa sejauh kurang lebih 1,5 meter di depan sensor kinect agar dapat teridentifikasi dengan baik oleh sensor. Kursor berbentuk tangan akan tampil di layar monitor ketika pengguna telah teridentifikasi oleh sensor dan kursor akan bergerak sesuai arah gerak tangan kanan pengguna. Jadi tangan kanan pengguna berfungsi sebagai controller sebuah game. Tombol pada aplikasi game bisa diklik dengan cara menggenggamkan tangan kanan sesaat kemudian melepasnya kembali tepat pada tombol.

\subsection{Halaman Awal}

Halaman awal akan muncul pertama kali saat program dijalankan. Ketika halaman ini muncul maka akan terdengar backsound musik sebagai pengiring aplikasi, serta 3 tombol yaitu tombol "Mulai" untuk memulai permainan, tombol "Petunjuk" untuk menampilkan tutorial berbasis teks cara memainkan game dan tombol "Keluar" untuk keluar dari aplikasi. Ketika pengguna memilih tombol "Mulai" maka halaman menu utama akan tampil. 


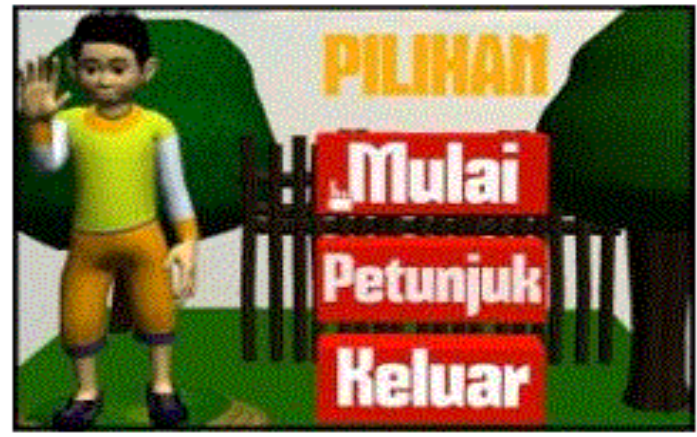

Gambar 2. Halaman Awal

\subsection{Halaman Menu Utama}

Halaman menu utama akan muncul setelah pengguna memilih tombol "Mulai" pada halaman awal. Beberapa menu pilihan pada halaman ini disajikan dalam beberapa variasi bentuk atau obyek. Kotak berbentuk televisi sebagai menu "Demo" yang berfungsi untuk melihat video animasi tentang merawat kebersihan diri, tumpukan kotak berbentuk balok mainan sebagai menu "Mulai" yang berguna untuk memulai permainan merawat diri, dan daun pintu sebagai menu "Keluar" yang berfungsi untuk keluar dari aplikasi game. Ketika menu utama tampil, maka maka akan terdengar audio yang menjelaskan fungsi masing-masing bentuk atau obyek.

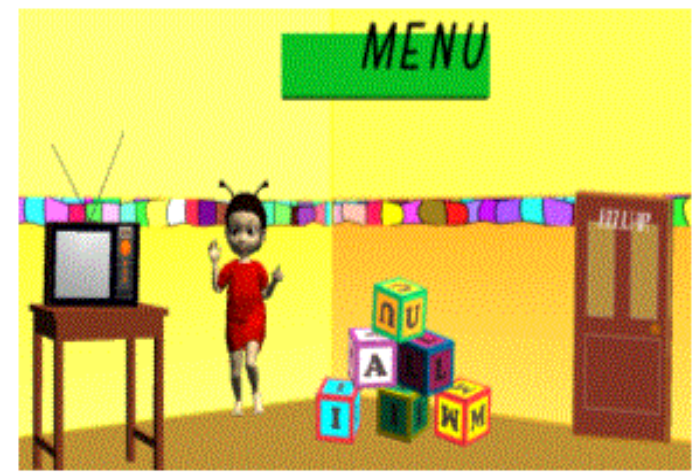

Gambar 3. Halaman Menu Utama

\subsection{Halaman Demo}

Halaman demo akan muncul apabila pengguna memilih obyek televisi pada halaman menu utama. Pada halaman ini ditampilkan beberapa anggota tubuh dan beberapa alat yang biasa digunakan untuk merawat anggota tubuh. Pengguna diminta memasangkan bagian anggota tubuh dengan alat yang sesuai. Anggota tubuh yang ditampilkan pada halam ini adalah rambut, gigi, tangan dan badan. Sedangkan alat alat-alat untuk merawat kebersihan anggota tubuh yang ditampilkan adalah shampo, sabun mandi, sabun pembersih tangan, dan sikat gigi. Drag and drop adalah cara untuk memasangkan gambar anggota tubuh dengan gambar alat kebersihan. Apabila pemasangan yang dilakukan oleh pengguna sesuai, maka akan tampil video animasi tentang cara membersihkan anggota tubuh yang telah dipasangkan. Sedangkan apabila pemasangan tidak sesuai, maka anggota tubuh yang di-“drag" akan kembali ke tempat semula dan video animasi tidak muncul. 


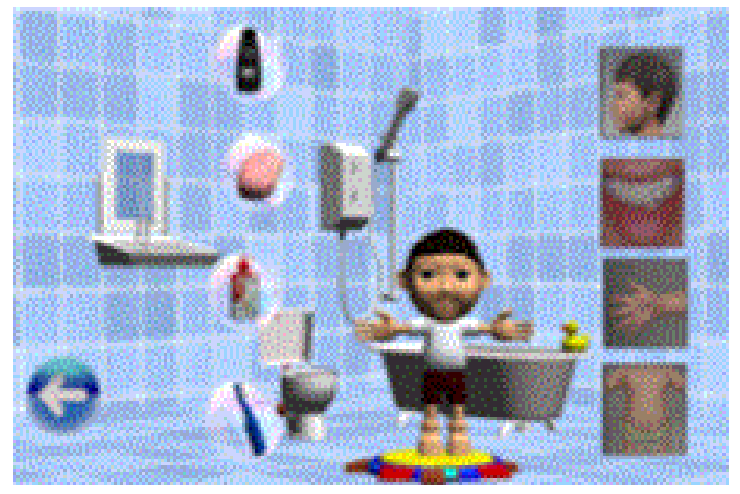

Gambar 4. Halaman Demo

\subsection{Halaman Mulai}

Halaman mulai akan muncul apabila pengguna memilih tumpukan balok mainan pada halaman menu utama. Pada halaman ini pengguna diberi dua tombol untuk dipilih, yaitu tombol "Ya" dan tombol "Tidak". Apabila pengguna memilih tombol "Ya", berarti pengguna menyetujui untuk memainkan misi seperti yang ditunjukkan pada gambar 6 . Sedangkan bila pengguna memilih tombol "Tidak" berarti tidak setuju untuk memainkan misi dan akan kembali ke halaman menu utama aplikasi.

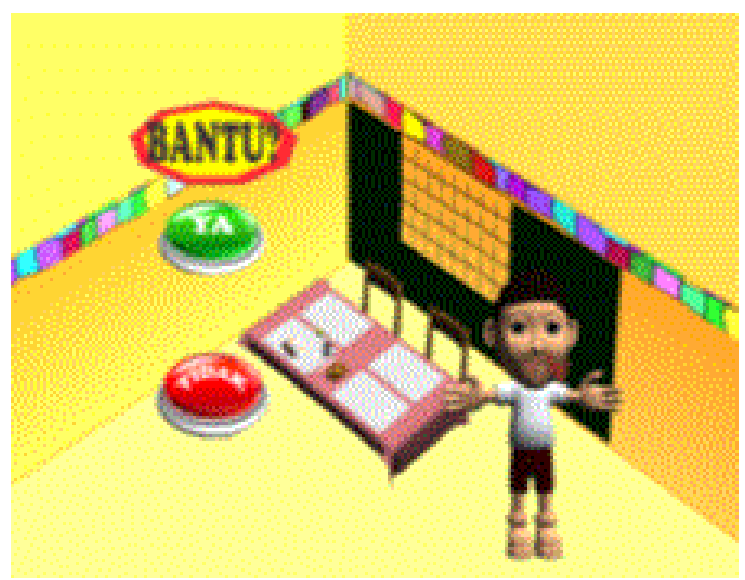

Gambar 5. Halaman Mulai

Gambar 6 menunjukkan halaman permainan. Tampak objek berbentuk sikat gigi dan objek gigi yang penuh dengan kuman dan kotoran. Misi pada permainan ini adalah pengguna diminta untuk membersihkan gigi dari kuman dan kotoran yang menempel dengan sikat gigi. Cara membersihkannya adalah dengan menggenggam sikat gigi menggunakan tangan kanan kemudian sikat digeser dan digerakgerakkan pada gigi-gigi yang kotor sampai semua kuman dan kotoran hilang. Permainan ini merupakan simulasi menggosok gigi. Apabila misi permainan menggosok gigi telah selesai maka pengguna dapat melanjutkan ke permainan berikutnya yaitu memotong kuku seperti ditunjukkan pada gambar 7 .

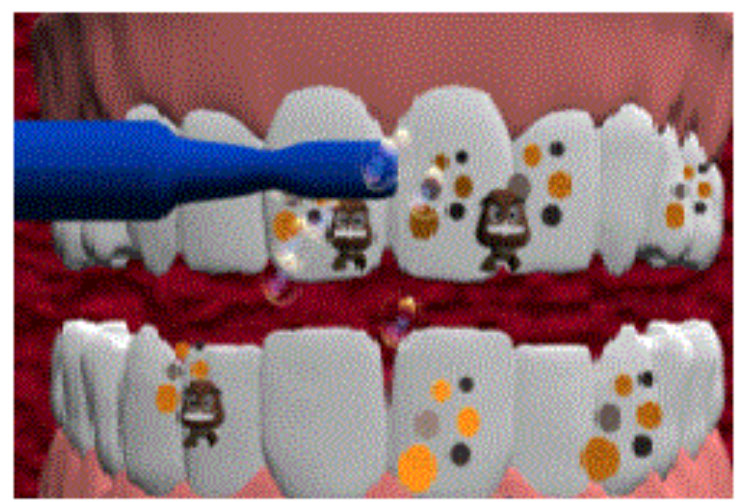

Gambar 6. Misi Game Tahap 1 


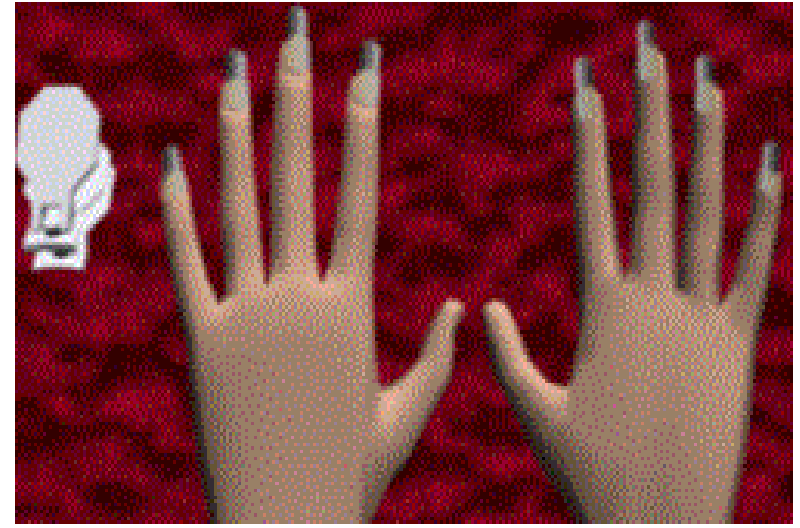

Gambar 7. Misi Game Tahap 2

Permainan selanjutnya setelah permainan menggosok gigi adalah misi memotong kuku. Pada halaman ini pengguna diminta untuk menggeser pemotong kuku dengan tangan kanan ke arah jari-jari yang memiliki kuku panjang. Proses pemotongan kuku bisa dilakukan dengan cara menggenggamkan tangan sesaat kemudian dilepas kembali pada saat pemotong kuku berada tepat di jari yang akan dipotong kukunya. Apabila semua kuku telah dipotong, maka permainan selesai dan kembali ke menu utama.

\section{PENGUJIAN}

Pengujian penelitian ini dilakukan di SLB-C YPSLB Kerten, Surakarta, Jawa Tengah dengan melibatkan murid kelas 1 SD SLB-C YPSLB yang didampingi beberapa guru. Murid-murid diberi kesempatan untuk mencoba sedangkan guru hanya mengamati game dan membimbing murid agar tetap fokus serta dapat mencoba game dengan baik. Peneliti memberikan kuesioner kepada guru-guru SLB untuk memberikan penilaian terhadap game yang telah didemonstrasikan. Penulis menggunakan metode kualitatif dalam mengolah data hasil kuesioner dikarenakan jumlah responden hanya sedikit. Berikut hasil analisa deskriptif dari kuesioner yang telah diisi oleh responden:

1) Tanggapan responden terhadap pernyataan nomor 1, yaitu "Tampilan game menarik", menyebutkan bahwa semua responden menjawab sangat setuju (SS). Artinya bahwa tampilan game edukasi pelatihan merawat diri untuk anak sekolah dasar berkebutuhan khusus tunagrahita ini sangat menarik bagi siswa-siswi SDLB-C YPSLB Surakarta.

2) Tanggapan responden terhadap pernyataan nomor 2, yaitu "Game bersifat interaktif", menyebutkan bahwa semua responden menjawab sangat setuju (SS). Artinya bahwa game edukasi pelatihan merawat diri yang menggunakan kinect untuk anak sekolah dasar berkebutuhan khusus tunagrahita ini merupakan game yang sangat interaktif bagi siswa-siswi SD SLB-C YPSLB Surakarta.

3) Tanggapan ketiga responden terhadap pernyataan nomor 3, yaitu "Game mudah dimainkan", menyebutkan bahwa semua responden menjawab setuju (S). Artinya bahwa game edukasi pelatihan merawat diri untuk anak sekolah dasar berkebutuhan khusus tunagrahita ini merupakan game yang mudah dimainkan. Hal ini disebabkan aplikasi game edukasi dengan fitur simple dan tidak membuat pengguna bingung dalam memainkan game ini, sehingga cukup mudah dimainkan.

4) Tanggapan responden terhadap pernyataan nomor 4, yaitu "Anak-anak antusias dengan game ini”, menyebutkan bahwa semua responden menjawab sangat setuju (SS). Artinya bahwa game edukasi pelatihan merawat diri untuk anak sekolah dasar berkebutuhan khusus tunagrahita ini sangat mampu membuat siswa antusias dalam memainkan game ini. Hal ini tidak terlepas dari peran guru yang membimbing muridnya selama game didemonstrasikan di kelas.

5) Tanggapan responden terhadap pernyataan nomor 5, yaitu "Game ini membuat anak tertarik belajar merawat diri”, menyebutkan bahwa semua responden menjawab sangat setuju (SS). Artinya bahwa game ini mendorong siswa tertarik untuk belajar merawat diri.

6) Tanggapan responden terhadap pernyataan nomor 6, yaitu "Materi sesuai kurikulum yang diajarkan", menyebutkan bahwa semua responden menjawab sangat setuju (SS). Artinya bahwa materi yang diberikan dalam game ini berisi materi yang sangat sesuai dengan kurikulum yang diajarkan pada SDLB-C YPSLB Surakarta, yaitu kurikulum yang disesuaikan dengan silabus tematik program khusus. 
7) Tanggapan responden terhadap pernyataan nomor 7, yaitu "Materi yang ada dalam game ini cukup membantu anak belajar meningkatkan kemampuan untuk merawat diri", menyebutkan bahwa semua responden menjawab sangat setuju (SS). Artinya bahwa materi yang ada di game ini tepat guna dan sangat membantu anak belajar meningkatkan kemampuan merawat diri.

8) Tanggapan responden terhadap pernyataan nomor 8, yaitu "Game dapat digunakan untuk membantu guru memberikan variasi dalam menyampaikan materi tentang perawatan diri”, menyebutkan bahwa semua responden menjawab sangat setuju (SS). Artinya bahwa game ini dapat membantu guru lebih bervariasi dalam memberikan pelajaran sehingga murid dalam menerima pelajaran tidak cepat merasa bosan.

9) Tanggapan responden terhadap pernyataan nomor 9, yaitu "Game ini secara keseluruhan dapat digunakan sebagai sarana bermain dan belajar", menyebutkan bahwa semua responden menjawab sangat setuju (SS). Artinya bahwa game sesuai dengan hasil wawancara dengan guru, yaitu secara keseluruhan dapat digunakan sebagai sarana bermain dan belajar siswa-siswi SDLBC YPSLB Surakarta.

10)Tanggapan responden terhadap pernyataan nomor 10, yaitu "Perangkat Kinect (sensor gerak) cukup mudah digunakan oleh para murid", menyebutkan bahwa sebagian besar responden menjawab netral $(\mathrm{N})$ dan sisanya menjawab setuju (S). Artinya bahwa perangkat Kinect yang digunakan sebagai game controller ini belum cukup mudah digunakan untuk anak berkebutuhan khusus tunagrahita. Guru menyarankan adanya pendampingan dan bimbingan ketika anak tunagrahita memainkan game ini.

11)Tanggapan ketiga responden terhadap pernyataan nomor 11, yaitu "Audio dalam game ini dapat dimengerti maknanya”, menyebutkan bahwa semua responden menjawab sangat setuju (SS). Artinya bahwa audio yang ada di game ini jelas didengar dan mudah difahami oleh murid dan guru.

\section{KESIMPULAN}

Berdasarkan hasil penelitian yang dilakukan dapat disimpulkan bahwa:

a) Seluruh responden menyatakan bahwa game edukasi ini menarik, interaktif dan materi yang tersedia dalam game ini dapat membantu anak tunagrahita belajar merawat diri khususnya menggosok gigi dan memotong kuku.

b) Penggunaan perangkat kinect pada game ini menjadikan game ini mudah dimainkan oleh anak tunagrahita kategori ringan, namun masih perlu adanya pendampingan dan pembimbingan ketika mereka memainkan game ini. Sekaligus membantu guru untuk lebih variatif dalam menyampaikan pelajaran.

\section{DAFTAR PUSTAKA}

[1] Al Irsyadi, Fatah Yasin. dan Nugroho, Yusuf Sulistyo. 2015, "Game Edukasi Pengenalan Anggota Tubuh dan Pengenalan Angka Untuk Anak Berkebutuhan Khusus (ABK) Tunagrahita Berbasis Kinect”. Prosiding Seminar Nasional Teknologi Dan Informatika SNATIF Universitas Muria Kudus. 13-20.

[2] Saptunar. 2012. "Meningkatkan Keterampilan Menyetrika Pakaian Anak Tunagrahita Sedang". Jurnal Ilmiah Pendidikan Khusus Universitas Negeri Padang 1. 1, 102-112.

[3] Sudarmilah, Endah.,et al. 2013." Tech Review: Game Platform for Upgrading Counting Ability on Preshool Children". Proceedings of 2013 International Conference on Information Technology and Electrical Engineering, 226-231.

[4] Usti, Afnita. 2013. "Meningkatkan Kemampuan Mengenal Angka Melalui Bermain Pancing Angka Bagi Anak Tunagrahita Ringan”. Jurnal Ilmiah Pendidikan Khusus Universitas Negeri Padang 1. 1, 478-488.

[5] Yang, Y. H., et al. 2014. "The application of KINECT motion sensing technology in game-oriented study”. International Journal of Emerging Technologies in Learning 2.2, 59-63. 